\title{
A MEDICAL CAREER: BARRIERS TO PROFESSIONAL IDENTITY
}

\author{
Mettini $E^{1}$, Yasko $B A^{2} \otimes$, Kazarin $\mathrm{BV}^{2}$, Ostroushko $\mathrm{MG}^{3}$
}

1 Pirogov Russian National Research Medical University, Moscow, Russia

${ }^{2}$ Kuban State Medical University, Krasnodar, Russia

${ }^{3}$ Regional Clinical Hospital № 2, Krasnodar, Russia

\begin{abstract}
Sometimes, a minor scientific event leaves a much more memorable trace than a large conference. On May 30-31, 2019, Pirogov Russian National Research Medical University hosted a symposium on medical identities in various communities. Reports, reviews and discussions presented at the symposium focused on the problem of identity, a unique phenomenon that results from self-reflecting on a complex dynamic process of personal development. Professional identity is particularly important for a medical doctor. This article inspired by the reports of our colleagues summarizes the results of the symposium.
\end{abstract}

Keywords: physician, identity, self-concept, professional identity, barriers, professional crisis, professiogenesis

Acknowledgement: the authors thank all participants of the symposium on Medical identities in different communities held on May 30-31, 2019 at Pirogov Russian National Research Medical University) whose reports inspired us to write this article.

Author contribution: Mettini E conceived the article and supervised its preparation; Yasko BA planned the article, systematized the concepts of identity and identity crisis used in the studies of healthcare workers; Kazarin BV suggested analyzing the role of postgraduate education in overcoming the barriers to professional identity in medical doctors; Ostroushko MG provided and analyzed empirical data.

$\triangle$ Correspondence should be addressed: Bela F. Yasko

Sedina 4, Krasnodar, 350063; shabela@yandex.ru

Received: 06.08.2019 Accepted: 21.08.2019 Published online: 26.08.2019

DOI: $10.24075 /$ brsmu.2019.055

\section{ПРОФЕССИОНАЛЬНЫЙ ПУТЬ ВРАЧА: «БАРЬЕРЫ» ИДЕНТИЧНОСТИ}

\author{
Э. Меттини , Б. А. Ясько ${ }^{2}$, Б. В. Казарин², М. Г. Остроушко
}

${ }_{1}^{1}$ Российский национальный исследовательский медицинский университет имени Н. И. Пирогова, Москва, Россия

2 Кубанский государственный медицинский университет, Краснодар, Россия

${ }^{3}$ Краевая клиническая больница № 2, Краснодар, Россия

\begin{abstract}
Незначительное по масштабам научное событие нередко оставляет след более выразительный, чем иная крупная конференция. В Российском национальном исследовательском медицинском университете имени Н. И. Пирогова 30-31 мая 2019 г. прошел симпозиум «Медицинские идентичности в разных обществах». Сделанные здесь доклады, обзоры, прошедшие в их контекстах дискуссии были посвящены проблеме идентичности уникальному явлению, формирующемуся как результат отрефлексированности субъектом сложного многогранного динамичного процесса личностного становления. Особую значимость, на наш взгляд, идентичность имеет в просессиональной жизни врача, что обусловило несомненную актуальность докладов и диалогов, составивших содержательность проведенного симпозиума, и целесообразность обобщения его результатов в виде предлагаемого читателю мнения.
\end{abstract}

Ключевые слова: врач, идентичность, Я-концепция, просессиональная идентичность, профессиональные барьеры, профессиональные кризисы, профессиогенез

Благодарности: авторы выражают благодарность всем участникам симпозиума «Медицинские идентичности в разных обществах» (РНИМУ имени Н. И. Пирогова, 30-31 мая 2019 г.), материалы выступлений которых позволили обобщить некоторые результаты научного взаимодействия в виде представленного мнения.

Информация о вкладе авторов: Э. Метини - идея публикации; общее руководство подготовкой публикации; Б. А. Ясько - план публикации, систематизация понятий «идентичность», «кризисы идентичности» в исследованиях субъектов медицинского труда; Б. В. Казарин - идея анализа роли последипломного образования в преодолении барьеров становления профессиональной идентичности врача-руководителя; М. Г. Остроушко предоставление эмпирического материала, первичный анализ эмпирических данных.

$\triangle$ Для корреспонденции: Бэла Аслановна Ясько

М. Седина, д. 4, г. Краснодар, 350063; shabela@yandex.ru

Статья получена: 06.08.2019 Статья принята к печати: 21.08.2019 Опубликована онлайн: 26.08.2019

DOI: 10.24075/vrgmu.2019.055

\section{Identity as a subject of human and social sciences}

For more than half a century, identity has been in the focus of human and social studies that deal with various aspects of human existence, personal development, self-actualization, responding to challenges and crises, and building lifestyle resources. Classic psychoanalytic works approached identification as a psychological defense mechanism [1, 2]; in contrast, E. Erikson in his epigenetic theory defined the search for identity as a developmental stage in adolescence [3]. As a phenomenon, identity is explored by philosophy, linguistics, culture and social studies of human beings and their social nature. Recent linguistic research has demonstrated that an increasing use of semiotic resources in shaping and expressing identity is one of key characteristics of this complex phenomenon [4]. In psychology, the concept of identity is also enjoying a surge of interest. Terms like personal, gender, group, ethnic, professional and organizational identities have entered the lexicon of psychologists and are widely used in psychotherapy and psychological consulting. The program of the 16th European Congress of Psychology held in Moscow in July 2019 included the symposium on Personal identity in the conditions of multi-vector changes in the society. This signals a profound interest in the phenomena of identity and identification across the scientific community. The participants of the discussion pointed out that multivector changes 
sweeping through the globe are complicating the process of personal identification affected by new social and technological challenges brought about by the advent of the digital era. The speakers talked about a new phenomenon of online identity [5] and about national identity that comes into being as a group of individuals reflects on its historical experience [6]. Risks for social failure are increasing, as seen from the rising number of cases of unconfirmed identity [7] and gender identity crisis [8].

\section{Professional identity of a medical doctor: the mystery of formation}

To understand what a doctor's professional identity really is, one has to identify a stage of medical training it starts to shape at, the factors involved and the intensity of the process. For a long time, little effort has been channeled into this field of research. On the whole, our foreign colleagues have paid more attention to this problem. Specifically, there have been persistent attempts to shed light on the nature and mechanisms of professional identity formation in the early stages of professional development. In medical students, professional identity is seen as a result of resolving difficult ethical dilemmas [9] and as an intrinsic part of a student's personality [10]. Some Russian authors have studied professional identity in the context of daily routine of young Russian physicians working in different environments (cities, towns or villages) [11]. Those authors discriminate between 3 types of professional identity, depending on which view on the profession dominates the mindset of a young physician: being a helper (a doctor is a helping profession), being an expert (a doctor is an expert in a medical field), or being a researcher (a doctor is a researcher focusing on academic science).

The concept of professional identity holds a central place in the contemporary labor psychology and is loaded with a wide range of meanings [12]. One of them is particularly important for grasping the essence of professional development: professional identity is an indicator of how well an individual, their expertise and professional achievements meet the healthcare demands posed by society, professional community and its corporate culture [12] Seeing professional identity as an ability to selfidentify in a profession can be used as a methodological landmark in research studies exploring the complexity of psychological aspects pertaining to the development of professional identity in healthcare workers [12]. Just like motivation, professional identity determines professionalism.

We face a lot of barriers in different stages of our career that put our professional identity at risk for shattering. Overcoming these barriers helps us to self-identify professionally at younger age and facilitates self-actualization later in life [13]. The barriers make one's professional path nonlinear and thereby create a prerequisite for redefining the vectors of the chosen carrier, prevent one from professional stagnation, and enhance their professional identity. Some of the barriers are purely individual experience; however, others are common to the entire medical profession. The latter include professional crises that need to be overcome in order to self-actualize [14].

\section{References}

1. Freud Z. Psihologija mass i analiz chelovecheskogo «Ja». SPb.: Azbuka-Attikus, 2013; 192 s. Russian.

2. Lacan J. Iznanka psihoanaliza. M.: Logos, 2008. 272 s. Russian.

3. Hjelle L, Ziegler D. Teorii lichnosti. SPb.: Piter, 2017; 608 s.

4. Molodichenko ER Identity and discourse: from social theory to
The first barrier is the problem of choice: a young individual torn by a conflict of motives and preferences creates a professional self-image and eventually decides in favor of a medical carrier. This crisis is a powerful stimulus: the decision to become a doctor means one has to accept responsibility, mobilize their internal resources and set off on a long and difficult journey of professional education. Achieved professional identity is a reward for overcoming this first barrier.

Other crises that will follow help an individual to build their confidence as a professional and to transform their self-image into a profession-related self-concept. Normative crises occurring in a medical carrier include crises in year 1 and 3 of medical training, a crisis related to the choice of specialty, a crisis at the start of a professional carrier, a crisis related to maintaining and improving qualifications, and a crisis of retirement.

The professional path of a medical doctor is also filled with obstacles that cause a risk for destroying his/her professional identity that include the so-called supernormative and extraordinary crises. An example of such a barrier is a crisis experienced when a doctor has to change their specialty or job. In this case, a typically normative crisis a person has to go through when starting a new job becomes supernormative or even acquires features of the extraordinary crisis that puts the doctor under a lot of stress. Such crises strike when a physician is offered a senior management position in a healthcare institution [15]. It is accompanied by frustration of a professional self-concept dissonant with a new identity (I as a senior executive). Studies have shown that in terms of confidence, "I in the present" becomes weaker than "I in the past", the person feels the lack of competencies required for a new position, engages in negative coping strategies, etc. $[15,16]$. Introducing the psychology of management into the curriculum taught to healthcare workers who study organization of healthcare and public health could help to overcome this barrier. Lectures and workshops on the psychology of management help students to develop standard competences that a senior executive is expected to demonstrate in their new position [17]. The essays and reports prepared by the graduates of the Department of Public Health and Healthcare (the Faculty of Continuous Professional Education, Kuban State Medical University) reveal a positive shift from frustration to realizing the points of integration between two professional identities: I as a physician and I as a senior executive.

\section{CONCLUSIONS}

Professional identity is the core of a person's self-image. This core not a monolith. It is subject to various interventions arising from changes, challenges and demands from both within and without. In order to succeed in medical profession and to overcome the barriers occurring in all stages of their professional career and throughout life, one has to understanding the meaning of those barriers. The significance of the problem discussed at the symposium necessitates research into the mechanisms, factors involved and patterns of professional identity formation in medical doctors living in contemporary society. 
Congress of Psychology (ECP 2019) (2-5 July, 2019. Lomonosov Moscow State University, Moscow). Moscow: Moscow University Press, 2019; 20.

6. Berberyan A, Tuchina O. Historical experience and national identity in the era of globalization. Book of Abstracts: XVI European Congress of Psychology (ECP 2019) (2-5 July, 2019. Lomonosov Moscow State University, Moscow). Moscow: Moscow University Press, 2019; 22-3.

7. Ryabikina Z, Makarevskaya Y. Unconfirmed identity as an indicator of social failure of personality. Book of Abstracts: XVI European Congress of Psychology (ECP 2019) (2-5 July, 2019. Lomonosov Moscow State University, Moscow). Moscow: Moscow University Press, 2019; 24.

8. Ozhigova L. Crisis of a person's gender-based identity. Personal identity in the conditions existence virtualization. Book of Abstracts: XVI European Congress of Psychology (ECP 2019) (2-5 July, 2019. Lomonosov Moscow State University, Moscow). Moscow: Moscow University Press, 2019; 26.

9. Binyamin G. Growing from Dilemmas: Developing a Professional Identity Through Collaborating Reflections on Relational Dilemmas. Advances in Health Sciences Education. 2018; 23 (1): 43-60.

10. Broadhead RS. The Private Lives and Professional Identity of Medical Students. London: Routledge, 2017; 140 p.

11. Galkin KA. Generational succession of medical students in the context of formation the professional identity. Socio-economic researches, humanities and law: theory and practice. 2017; (13): 62-6.
12. Ermolaeva EP. The relationship of identity, relevance and marginalization of the professional in modern society. In: A. A. Oboznov, A. L. Zhuravlev, editors. Actual problems of labor psychology, engineering psychology and ergonomics. Issue 7. M.: Institute of psychology RAS, 2015; 11- 22.

13. Cimanuk EE, Devyatovskaya IV. Continuous education as a resource of overcoming of psychological barriers in the process of professional development. Education and science. 2015; (1): 80-92.

14. Yasko BA. Organizational psychology of health care: personnel, leadership, culture. Monograph. Krasnodar: Kuban. State. Un-t, 2013; 260 p.

15. Tkhagalegova LV. Treatment of time and psychology of life and existential crises. Book of Abstracts: XXII International Symposium "Psychological problems of meaning of life and Acme". Moscow: PI RAO, 2017; 294-5.

16. Yasko BA, Kasarin BV, Rimmavi MH. Basics of administrative competence of a doctor-head as a subject in a post graduate education system. International Journal of Experimental Education. 2011; (1): 15-7.

17. Ob utverzhdenii professional'nogo standarta «Specialist v oblast organizacii zdravoohraneniya i obshhestvennogo zdorov'ja". Prikaz Ministerstva truda i social'noj zashhity RF ot 7 noyabrya 2017 g. \# 768n. Dostupno po ssylke: https://www.garant.ru/ products/ipo/prime/doc/71722794/. Russian.

\section{Литература}

1. Фрейд З. Психология масс и анализ человеческого «Я». СПб.: Азбука-Аттикус, 2013; 192 с.

2. Лакан Ж. Изнанка психоанализа. М.: Логос, 2008; 272 с.

3. Х Хелл Л., Зиглер Д. Теории личности. СПб.: Питер, 2017; 608 с.

4. Молодыченко Е. Р. Идентичность и дискурс: от социальной теории к практике лингвистического анализа. Научнотехнические ведомости Санкт-петербургского государственного политехнического университета. Гуманитарные и общественные науки. 2017; 8 (3); 122-30.

5. Ryabikina Z, Bogomolova K. Personal identity in the conditions existence virtualization. Book of Abstracts: XVI European Congress of Psychology (ECP 2019) (2-5 July, 2019. Lomonosov Moscow State University, Moscow). Moscow: Moscow University Press, 2019; 20.

6. Berberyan A, Tuchina O. Historical experience and national identity in the era of globalization. Book of Abstracts: XVI European Congress of Psychology (ECP 2019) (2-5 July, 2019. Lomonosov Moscow State University, Moscow). Moscow: Moscow University Press, 2019; 22-3.

7. Ryabikina Z, Makarevskaya Y. Unconfirmed identity as an indicato of social failure of personality. Book of Abstracts: XVI European Congress of Psychology (ECP 2019) (2-5 July, 2019. Lomonosov Moscow State University, Moscow). Moscow: Moscow University Press, 2019; 24.

8. Ozhigova L. Crisis of a person's gender-based identity. Personal identity in the conditions existence virtualization. Book of Abstracts: XVI European Congress of Psychology (ECP 2019) (2-5 July, 2019. Lomonosov Moscow State University, Moscow). Moscow: Moscow University Press, 2019; 26.

9. Binyamin G. Growing from Dilemmas: Developing a Professional Identity Through Collaborating Reflections on Relational Dilemmas. Advances in Health Sciences Education. 2018; 23 (1): 43-60.

10. Broadhead RS. The Private Lives and Professional Identity of Medical Students. London: Routledge, 2017; 140 p.

11. Галкин К. А. Поколенческая преемственность студентов врачей в контексте формирования профессиональной идентичности. Социально-экономические исследования, гуманитарные науки и юриспруденция: теория и практика. 2017; (13): 62-6.

12. Ермолаева Е. П. Взаимосвязь идентичности, востребованности и маргинализма профессионала в современном обществе. В книге: Обознов А. А., Журавлев А. Л., редакторы. Актуальные проблемы психологии труда, инженерной психологии и эргономики. Выпуск 7. М.: Институт психологии РАН, 2015; с. $11-22$.

13. Сыманюк Э. Э., Девятовская И. В. Непрерывное образование как ресурс преодоления психологических барьеров в процессе профессионального развития. Образование и наука. 2015; (1): 80-92.

14. Ясько Б. А. Организационная психология здравоохранения: персонал, лидерство, культура. Монография. Краснодар: Кубан. гос. ун-т, 2013; 260 с.

15. Тхагалижокова Л. В. Отношение ко времени и психология жизненных и экзистенциальных кризисов. Материалы XXII Международного симпозиума «Психологические проблемь смысла жизни и акме». Москва: ПИ РАО, 2017.

16. Yasko BA, Kasarin BV, Rimmavi MH. Basics of administrative competence of a doctor-head as a subject in a post graduate education system. International Journal of Experimental Education. 2011; (1): 15-17.

17. Об утверждении профессионального стандарта «Специалист в области организации здравоохранения и общественного здоровья». Приказ Министерства труда и социальной защиты РФ от 7 ноября 2017 г. № 768н. Доступно по ссылке: https:// www.garant.ru/products/ipo/prime/doc/71722794/. 